\title{
Homeobox Protein Nkx-2.5
}

National Cancer Institute

\section{Source}

National Cancer Institute. Homeobox Protein Nkx-2.5. NCI Thesaurus. Code C102512.

Homeobox protein Nkx-2.5 (324 aa, $\sim 35 \mathrm{kDa}$ ) is encoded by the human NKX2-5 gene.

This protein plays a role in myocardial differentiation. 